\title{
真珠尰コレステリン結晶の各種検查所見
}

\author{
東京女子医科大学耳鼻咽喉科学教室（主任教授：岩本彦之䵩) \\ 荒牧暻是是
}

要旨

1. 目的

真珠腫性中耳炎の診断法の一つとしてコレステリン結晶の耳漏内検出が岁り，従来一般光学影微鏡に よるコレステリン結晶の検出が行なわれているが，実際には検出困難な埸合が多い，そこで(1)㣯光影微 鏡，(2)光学顕徽鏡，(3)電子顕徵鏡，(4)X線回折にょり真珠腫性中耳炎患者より手術時に摘出したMatrix 内のコレステリン結晶を観察し，臨床的応用について娭討したので報告する。

2. 万 法

材料は真珠董性中耳炎 13 耳より摘出した真珠属のコレステリン結晶を用いた。採取部位は固有鼓室 4 例，上鼓室 3 例，乳突洞 4 例，乳乫蜂巣 2 例，である。観察方法は(1)偏光顯微鏡による方法：偏光装 置付䫓徽鏡を使用し，100倍〜400倍で観察，(2)光学顕微鏡による方法：真珠腫を，(a)無染色，(b)H.E.染 色，(c)脂肪染色，(d)Masson Trichrom 染色，を行った後観察した。(3)電子顕徽鏡による方法：採取した 真珠腫の標本をリン酸綏衙液で洗浄した後，0.1\%オスミック酸で固定，次にアルコールに上り脱水， $\mathrm{QY}_{1}$ に通し，EPN 812て包埋，ウルトラミクロトームを使用し，ガラスナイフにて超薄切片を作り鉛染 色をはとこし，JEM-T5 型電子顕铰鏡で 10,000倍で観察，撮影した。なお対照実験として1\%ぜラチ ン包埋したコレステリン結晶を同方法により観察した。(4)X線回折法：採取した真珠腫と純粋なコレス テリン結晶のX線回折を行ない比較した。

成絃：偏光検鏡した13例すへてて大小租々の板状矩形ないし药形のあさやかな青色和よび登色の結晶 が認められた。しかしコレステリン結晶の大きさは一定せず,あるいは配列の層状のものゃ，散主性の ものなどがあつたが採取部位による結晶の形態上のちがいは認められなかつた．次に偏光覱锁鏡により コレステリン結晶の存在を確認してから種ぬの染色後光学㩆微鏡により観察した。しかしこの方法では コレステリン結晶を認めることが出来なかつた，次に電子顕溦鏡では角化層，顆粒層，有棘層に黑い斑

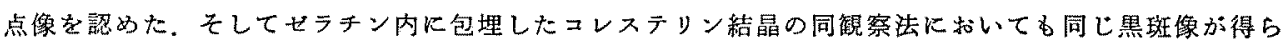
れた．X線回折に括いては真珠嗹のコレステリン結晶と純粋コレステリン結晶とも一致するX線回折曲 線を得た。

3. 結 馀

(1)偏光顕微鏡によればコレステリン結晶は青色扰よび橙色の矩形ないし菱形の結晶として容易にみと められる。この方法は操作の容易さと高い検出棉から臨床的方法として充分利用する価值がある。(2)染

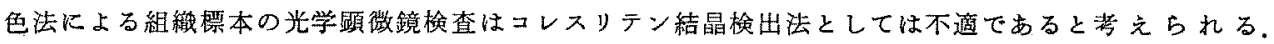
(3)電子影微鏡によればコレステリン結晶は黑斑像として写したされるるのと考えられる。(4)電子顕徽鏡

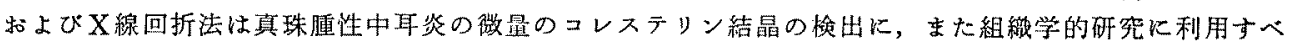
き方法と落える。

\section{第I章 緒言}

真珠連性中耳㷋の診断には耳鏡検査による悪性の鼓膜 毞孔や，覀臭ある耳漏，またX線写真による乳突洞附近 の大きな透明像などによりきめられ，とくに耳漏中のコ レステリン結晶の証明がその診断のきめてとされる。 し かしこのコレステリン結晶は一般検鏡によつて，簡単明 瞭に観察されるとはいいがたく，その診断的応用は充分
になされていない．そこで真珠厘倣断利用の見地からコ レステリン結晶を数種の方法, すなわち一般光学影微 鏡，倔光顕微鏡，電子顕微鏡，X線回折によつて 觀察 し，検討したので報告する。

第II章 研究材料

材料は当科における真珠尰性中耳炎の診断のもとに手 術を行なつた患者の真珠湩を用いた.これらの症例につ 
表 1 検查例

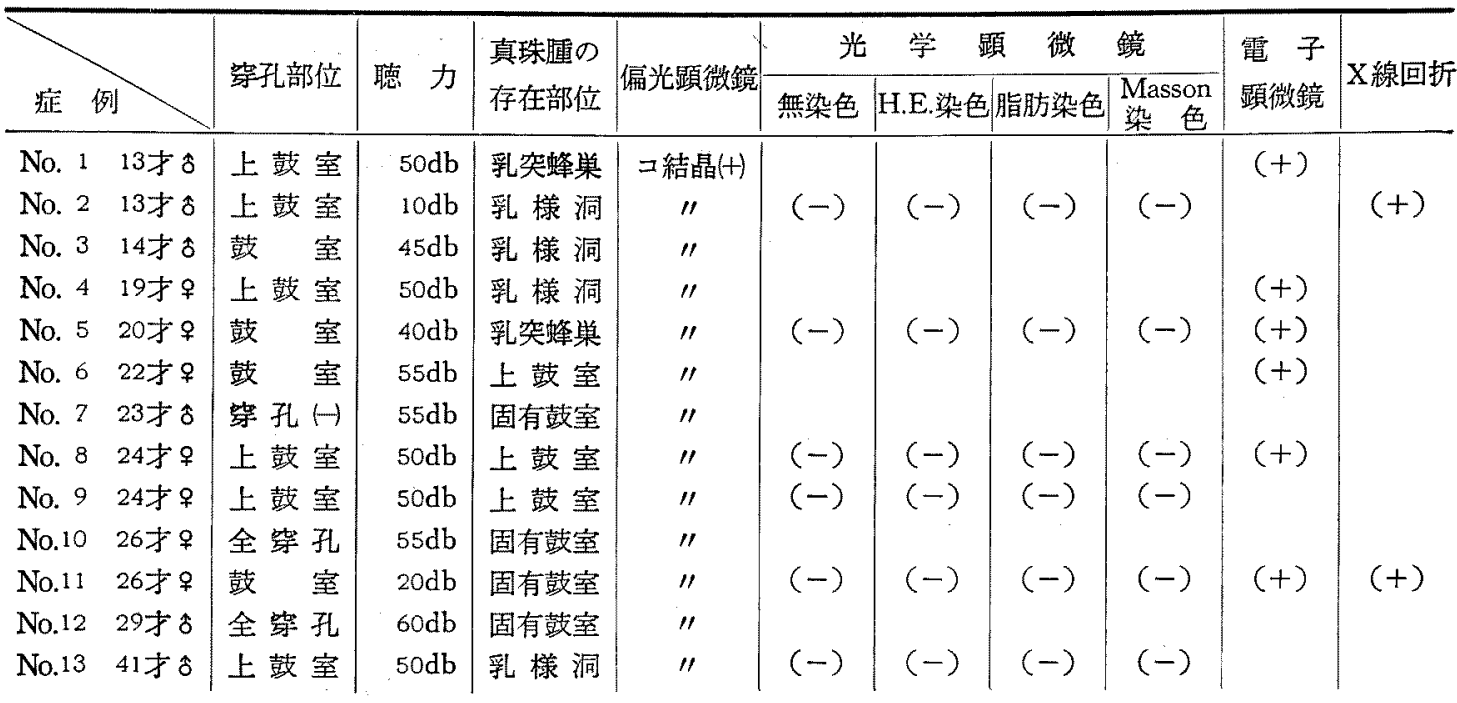

いて注 1 に示すごとく，男 6 例，女 7 例の計13例で年 令は13才から41才である。自覚症状は耳漏, 難㯖、耳 鳴，めまいである．敬膜所見は上鼓室穿孔6例，鼓室穿

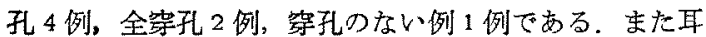
漏法60\%に認的られ，すべてに悪臭を伴つた. 聴力損失 は10 60dbで, 平均35dbであつた。

操取部位任固有鼓室 4 例, 上鼓室 3 例, 乳突洞 4 例, 乳突蜂单 2 例，で標本梳採取後ただちに少量の蒸留水を 加え常温で保存し，その小片を用いた。

\section{第且章 研究方法}

偏光顕微鏡法, 光学顕微鏡法, 電子顕微鏡法, X線回 折法により観察した。

1) 偏光䫓微鏡法

真珠隀塊の一部に少量の蒸留水を加え，スライドグラ スにのせ，偏光装置付顕微鏡に上り観察した，倍率は 100 400倍で直交ニコル間で鋴敏色検板を插入し，微弱 な複届折も観察した。

\section{2 ) 光学顕微鏡法}

手術時採取した真珠腫をただちにCO.凍結固定し，ミ クロトームにて切片を作り，100倍から200倍にて観察し t.

\section{a. 無染色 \\ b. H.E.染色}

a で観察した切片をただちにH.E液にて染色し, 検鏡 する:

c. 脂肪染色
同様な切片を Sudan III 液あるいはオイルレッド液に て染色し検鏡した。

\section{d. Masson Trichrom 染色}

真珠腯をホルマリン固定した標本を Masson Trichrom 液にて染色検鏡した。

\section{3) 電子顕微鏡法}

手術時探取した標本をリン酸経衝液で洗浄したのち， 0.1\%オスミック酸で固定，つぎにアルコールにより脱 水， $\mathrm{QY}_{1}$ に通し，EPN812で包埋した。 さらにウルトラ ミクロトームを使用し，ガラスナイフにて超薄切片を作 り，鉛染色索ほどこし，JEM-T5型電子顕微鏡 10,000 倍 で観察し, 撮影した。

4) X線回折法

真珠楿中のコレステリン結晶㧍よび純粋なコレステリ ン結晶を自動記録式X線回折曲線ディフラクトメーター (ガイガーフレックス)にかけて，それによつて得たX 線回折図を比較した。

\section{第IV章 研究成績}

\section{1) 偏光顕微鏡法}

13例について観察を行ない，全例にコレステリン結晶 を認めた。（表 1)

コレステリン結晶の大きさは一定せず，形はおむに板 状菱形あるいは板状矩形をていし，色は鋭敏色検板を插 入し，回転ステージを回転すると青色拉よび䇺色をてい した（図 1)（図 2）。また配列は層状のものや，散在性 のもの，また现立性のものなど種々あつた，症例や年 
令, 採取部位によるコレステリン結晶の形の相異は認め られなかつた、しかし症例によりコレステリン結晶の量 的差は認められた。この力法により真珠腫のコレステり ン結晶一つ一つが简単にまた明確に観察できた。

\section{2 ) 光学顕微鏡法}

おのおの 6 例について観察したが，いずれもコレステ リン結晶は認められなかつた。しかしのらにこれらの標 本を偏光顕微鏡で観察するとコレステリン結晶は存在す ることが認められた。

\section{3 ) 電子顕微鏡法}

6例について検查したところ, 図 3 のごとく角化層, 顆粒層, 有梀層に黒い斑点が見られた。そしてほかにコ レステリン結晶と考えられる所見は認められなかつた。 そこで黒玟像がコレステリン結晶か否かを確認するた め，純粋なコレステリン結晶を $1 \%$ ぜラチンに混入し， 前と同様の方法で，電子顕微鏡下に観察したところ，図 4 のごとく同様の黒斑像が認められた，さらに直接電子 顕微鏡の操作による電子線回折像の解折によりこれがコ レステリンー水和物であることを認めた.

\section{4) X線回折法}

2 例について検查を行なつた。その結果，図5のごと き回折図を得た。これが純粋なコレステリン結晶と同じ 回析図6を得た。

\section{第 V章 考按}

真珠㹸性中耳炎は，抗生物質療法の発達した現在に掠 いても，しばしば遭遇する疾患でその難治なことおよ び頭盖内合併症といつた危険性を有するゆえ，ぜひとも ほかの中耳炎と鑑別診断を要する疾患である。

現在鼓膜の辺縁驾孔，要臭ある耳漏，真珠腫の視䪭， $\mathrm{X}$ 線写真による乳突洞附近の透明像などの所見により診 断されるが，とくに耳漏中のコレステリン結晶の存在に より決定される。しかし一般臨床上これらの所見がすの゙ て認的られるとはかぎらず，診断決定に困難をきたす場 合が多い，佐藤”は 3 分の 2 以上は臨床所見では真珠腫 性中耳炎の診断は困難との心゙ている.Schreiner 2は上鼓 室寗孔の90\%が真珠腫とのベているが，著者の症例では 上鼓室案孔が 6 例，鼓室哱孔が 4 例，全案孔が 2 例であ り，また案孔のない例が 1 例である，また上鼓室疑孔は 岩沢3) は20\%とのべているところから，上鼓室の穿孔が ある例恃比較的少ない，全穿孔は著者は $15.4 \%$ ，岩沢 ${ }^{3}$ は45.2\%に認め，さらになかには山田"), 佐藤”, Buckingham $^{6)}$ ，三宅(5) らの報告にもるるよらに穿孔のない 例も諗めるところから，慗孔部位による診断は困難であ
る. 聴力は鼓膜の小穿孔の数 $\mathrm{db}$ 損失加ら耳小骨の欠損 した場合の50〜60dbの損失例とさまざまであり，これの みによつても診断を決定することはできない．また耳の レントゲン検查として, 硬化型乳突像や，乳突洞附近に 生ずる透明像による診断のほか，50\%ストロンチウムを 跂室内に注入し，レントゲン撮影する方法があるが，こ れは一般化されていない.そこでこの診断のために武 $\mathbb{1}^{7)}$, Berberich ${ }^{8)}$ は耳ポリープや, 肉芽組織中の脂肪組 織の化学的娭查を行なつているが一般的には利用されて いない.

それゆえ真珠属性中耳炎の診断にはやはりその中に含 まれるコレステリン結晶の検出が必要となつてくる。し かし一般光学顕微鏡法では，無染色においてもまた種々 の染色法においても，コレステリン結晶検出は非常に图 難で著者の症例においては全例コレステリン結晶は認め られなかつた。これは標本をのちに偏光法により，再観 察すると，コレステリン結晶が明らかに検出されるゆえ に、コレステリン結晶が固定染色の過程において溶解し たといらことでなく，一般光学顕微鏡によっては観察し にくいといらことである。

とくにコレステリン結晶が表面にあらわれていない場 合，た耳漏中コレステリン結晶のごとく，数片の結晶 しか存在しない場合は検出される可能性はかなり低いと 考えられる。そこで Rejtö ${ }^{9}$ ，本郷10) らは豉室内に四塩 化炭素を注入洗浄し，その洗浄液を比色することによ り、コレステリン結晶の検出をこころみ，高率にコレス テリン结晶を認めたとのベている，偏光顕微鏡は従来複 屈护体と等方体との鑑別に用いられている。

真珠腫中のコレステリンは結晶として存在するため, コレステリン結晶の検出法として佰光影微鏡の利用が考 えられた.この方法によればコレステリン結晶は青色な いし橙色の板状菱形，あるいは矩形をていし，またコレ ステリンの形や大きさは真珠䦎の摘出部位や，真珠䐸の 大きさとは関係なく，すべて先きにのべたような形を呈 した.

この方法によれば数片のコレステリン結晶でも存在す れば簡䍩に発見することが可能で，著者の実験では 100 \%にコレステリン結晶を認めることができた，とくに一 般検查法において発見しえなかつた襟本にもコレステリ ン結晶を見い出し得たことはこの方法が操作の簡単なこ ととあるせ臨床診断に充分利用できるものと考えられ

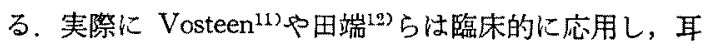
漏中のコレステリン結晶も真珠隀より直接除去したコレ 
ステリン結晶と同様の所見を認め，とくに田端12》らは 83\%に真珠連の診断が的中したとのべている。

それ西え、こんごの耳漏中のコレステリン結晶検出に はまず偏光顕微鏡を使用すべきであるといらことができ る. しかし著者らの偏光頭微鏡による耳拮の検查 ${ }^{130}$ で は、この中にコレステリン結晶が健康者の70\%にふくま れていることが判明したので，真珠腪性中耳炎影断のた めには鼓室内からの耳漏を検查しなければならない，

次に電子顕微鏡の結果, 黒い侮点像を認め, ほかにコ レステリン結晶像と思われる所見はえられなかつた。こ れまで真珠尰性中耳炎に㧍けるコレステリン結晶の電子 顕微鏡的観察を行なつた例は文献上みられなかつた．坂 本 ${ }^{14)}$ はコレステリン肉芽通組織中のコレステリン結晶を 観察している．そしてコレステリン肉芽嗹内のコレステ リン結晶は Millonig 法による1\%オスミック酸固定, およびアセトン上昇により，コレステリン結晶はアセト ン溶液内に溶出し，コレステリンの抜け殼，すなわちコ レステリンクレフトとして標本中にネガティブ像として 観察されたとのべている．そこで対照実験として，純粋 なコレステリン結晶をゼラチン内に包埋し，同じ検査法 により観察した.

その結果同じ黒斑像をえられたので，この黑斑像がコ レステリン結昆の可能性が強いと考える，また直接電子 顕微鏡の操作による電子回折像の解折によってもこの結 晶がコレステリン一水和物であることが証明された．X 線回折法による報告もこれまでなされていない，X線は 結晶により回折をおこすことがしられている。

そこでこれ利用し，絽粋なコレステリン結晶と真珠 畽のコレステリン結晶標本より得たX線回折図を比較検 討する方法を考えた.

これにより図6に示したごとく、純粋なコレステリン 結晶と同様の回折図が得られ，コレステリン結晶の存在 することが認められるもので，比較的簡単に検查するこ とができた．それゆえX線回折法は電子顕微鏡法ととも に微量のコレステリン結晶の検出に必要なものと考え る.

\section{第VI章 結 語}

真珠腫性中耳炎患者より摘出した真珠腫中のコレステ リン結晶を 1) 偏光顕微鏡, 2) 光学顕微鏡, 3) 電子 顕微鏡，4）X線回折, により観察した.

その結果偏光顕微鏡法では全例に青色ないし橙色を呈 する大小さまざまの板状菱形, 板状矩形のコレステリン 結晶を認めた．この方法は操作の容易さと，検出率の高
さから臨床的空用価值があると考えた。

光学䫓微鏡はコレステリン結昆の検出法として使用す るにはその検出率よりかなり困難であることがわかつ た，電子顕微鏡ではコレステリン結晶は黒斑像として得 られると考えた. X線回折法, 電子顕微鏡沬真珠腫性中 耳炎の微量の結晶の検出にまた組織学的研究に利用す心゙ き方法である。

\section{文献}

1）佐藤謙介：耳真珠腫の臨床診断と手術所見の比較に ついて。新渴医会誌, $70 ; 336 \sim 339,1956$.

2) Schreiner, L.: Zur Differentialdiagnose von primaren Cholesteatomen. Z. Laryng. Rhinol., 41 ; 121-126, 1956.

3）岩沢武彦他：真珠盾性中耳焱炕関する臨床的観察. 耳喉, 36；21 36, 1964 .

4) 山田喜郎他：鼓膜飞第孔を認め得ざりし中仮性真 珠腫症例。耳喉, $22 ; 5,1950$.

5) Buckingham, R.A., Valvassor, G.E.,: Tomographic and surgical pathology of cholesteatoma. Arch. Otolaryng., $91 ; 464-469,1970$.

6）三宅弘，他：鼓膜穿孔を認めなかつを中耳真珠缠の

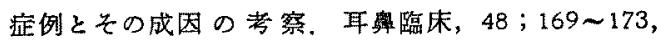
1955.

7) 武田貫美他：耳真珠腫症の臨床的並に之の脂肪の組 織化学観察. 耳鼻臨床. $43 ; 305 \sim 308 ， 1950$.

8) Berberich: Das Mittelohrcholesteatom. Experimentelle und pathologische-anatomische Untersuchungen. Zur Anat. Physiol. Pathol. u. Therapie des O.N. u. H. Hals, $26 ; 1-19,1928$.

9) Rejtö, A.: Cholesteatoma-Some new principles in its treatment, including the test for chemical demonstration. Arch. Otolaryng., 13; 709-713, 1931.

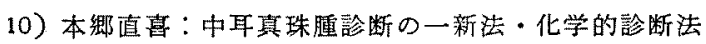
にっいて. 大日耳鼻, 38；395 412, 1932.

11) Vosteen, K.H.: Mikroskopische Untersuchung von Cholesteatomeiter im polarisierten Licht. H.N.O. (Berl.), $5 ; 371,1956$.

12）田端敏秀他・偏光顕微鏡飞よる真珠埂性中耳炎患者 の耳漏のコレステリン結晶の研究。日耳奥, 20；1501 $\sim 1506,1967$.

13）岩本彦之髙・荒牧昌子他：偏光顕微鏡に上る耳佑の コレステリン結晶の钼察.耳率，17,108〜110, 1971 .

14）坂本 毅：ヒトの耳炕生じるコレステリン肉芽腫の 
荒牧論文付図

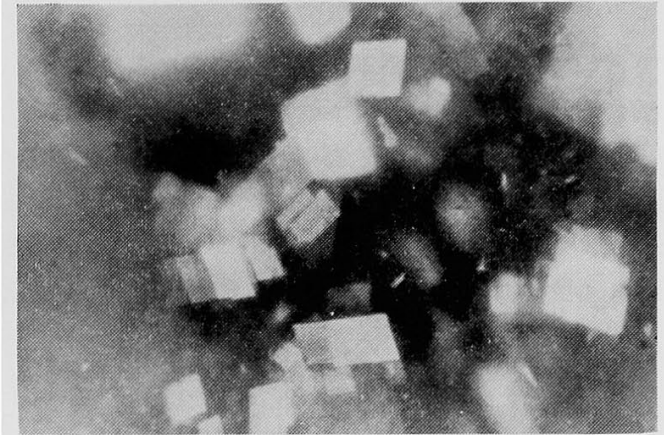

図 1 偏光䫓徵鏡によるコレステリン結晶散在性の もの $400 \times$

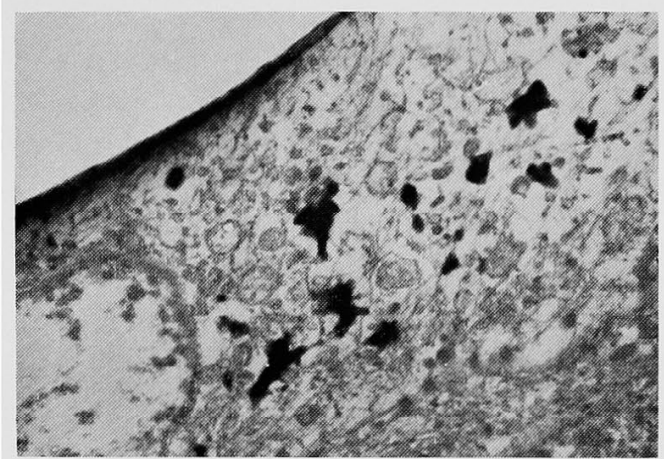

図 3 電子顕微鏡による真珠腫の黒斑像

$5000 \times(\times 2)$

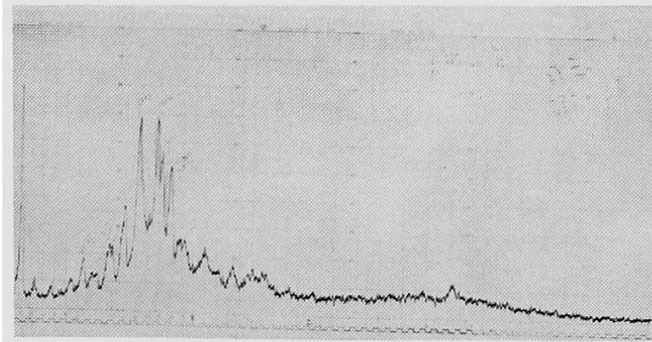

図 5 真珠腫中のコレステリン結晶のX $\mathrm{X}$ 線回折図

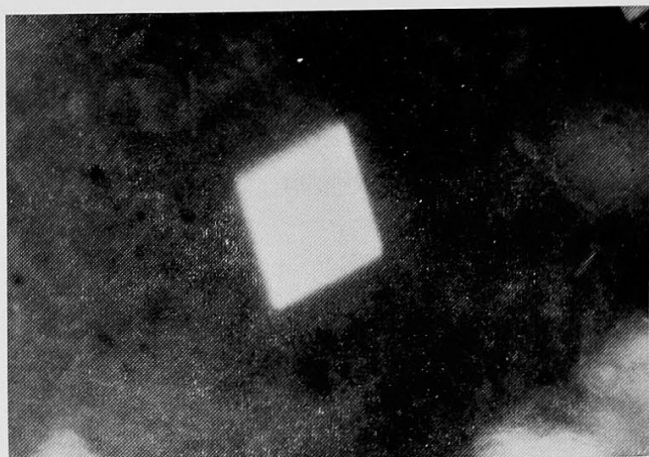

図 2 孤立性のもの

$400 x$

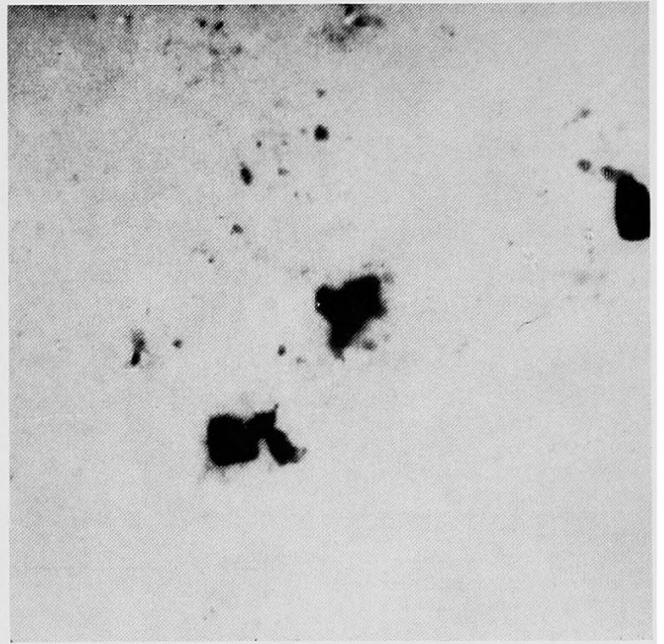

図 4 化学的コレステリン結晶のゼラチン包埋標本 の電子顕徴鏡像 $5000 \times(\times 2)$

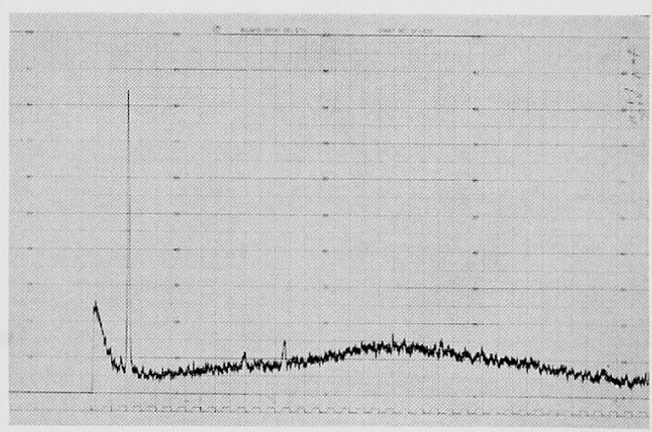

図 6 純料なコレステリン結晶の $\mathrm{X}$ 線回折図 
コレステリン結晶発生機序に関する電子画微鏡的研

究. 日耳菑，70；1926 1931，1967.

稿を終ると臨み御愁䉆な御指道之御校閲を賜わり ました本学耳鼻科教授碞本彦之舆先生ならびに物理 学教授佐藤弘一先生に深謝致します，又湖教示下さ
いました助教授上村卓也先生に厚くお礼申し上げま t.

（本論文の要旨は第56回関東地方会大会および第 72回日本耳算咽喉科学会絰会に执いて報告した。) 